\title{
An International Comparison on Excessive Credit Expansion, Credit Guarantee Programs and The Risks Arising
}

\author{
K. Batu Tunay ${ }^{1}$, Hasan F. Yuceyılmaz ${ }^{2 *}$, Ahmet Çilesiz ${ }^{3}$ \\ ${ }^{1}$ Marmara University, Istanbul, Turkey; ${ }^{2}$ Ziraat Bank; ${ }^{3}$ Independent financial advisor \\ *Corresponding author: hyuceyilmaz@gmail.com
}

\begin{abstract}
Crediting in the banking sector plays an important role in all developed and developing countries. For this reason, it is monitored continuously by public authorities and measures are taken to control credit supply in economic growth periods. On the other hand, in an economic slowdown, when banks are reluctant to increase their credit portfolio, public credit guarantee programs are put into use to increase the credit supply.

In this study, a sample covering 26 advanced and emerging economies was analyzed, and the effects of credit gap, credit guarantees and economic growth on credits and arising credit risks were investigated. The findings show that both credits and non-performing loans, an important measure of credit risk, are affected by credit gap, credit guarantees, and economic growth. On the one hand, public credit guarantees positively affect economic growth. On the other hand, though they are widely used for supporting small and medium-sized enterprises, our findings suggest that such expansive credit policies might negatively affect the riskiness of the credit portfolios and soundness of the banking sector.
\end{abstract}

Keywords: credit expansion, credit gap, systemic risk, credit guarantees, procyclicality.

\section{Introduction}

Credits make an essential contribution to the development of national economies. Excessive credit expansion, similar to inadequate credits, also has the potential to harm economic activity. Therefore, the credit amount provided by banks and credit institutions, proper administration of the credits, and good management of nonperforming loans within the framework of laws and regulations of the country are assessed as a whole and are monitored closely by the public authorities. The soundness of the banking and financial system are strictly related to the correct management of this cycle under country conditions. 
It is expected that the banking system will grow within its dynamics and due to the country's economic conditions. However, from time to time, the growth figures may differ from their long-term values. The emerging trend naturally draws the attention of authorities, and the question of whether overgrowth is healthy is to be researched. The IMF's 2004 World Economic Outlook Report indicates that excessive credit expansion in developing countries is as high as $75 \%$ related to the financial crisis.

In the growth period of the economy, while banks are increasing their loans rapidly, their balance sheets grow. When the economy enters a period of contraction, the credits are undergoing a sharp contraction. As a result, the decrease in the supply of credit during the downturn, as well as the excessive credit expansion, which is observed during periods of economic growth, act as a kind of accelerator, enhancing the economic cycle.

The findings of many empirical studies also support these determinations. Borio and Lowe (2002), Frömmel (2006), Riiser (2005 and 2008), Rheinberger \& Summer (2008), Gerdermeier (2009), Misina \& Tkacz (2009), Llaudes et al. (2010) have empirically shown that bank lending is effective in interacting with various financial assets on the procyclical instability of the financial system. On the other hand, Davis \& Dilruba (2008), Repullo et al. (2009), Jokivuolle et al. (2009), Gruss \& Sgherri (2009) have determined that procyclical movements of asset prices cause significant problems in the credit risk estimation process. These findings suggest that the procyclicality of asset prices is a key component of the mechanism between excessive credit expansion and the instability of the financial system.

Measures to prevent excessive credit expansion within the scope of countercyclical measures have been put in place together with the Basel III framework after the 2008-2009 global crisis. On the other hand, the loans granted by banks and financial institutions have shrunk rapidly during the last global financial crisis. In this case, authorities have supported the increase in credit supply through credit guarantee programs (OECD, 2010, 2012, 2013; World Bank, 2013).

Our study, in the light of these findings and assessments, is intended empirically to analyze the risks and fragilities that may be caused by excessive credit increases induced by credit guarantee programs. The main question to be answered in the study is whether such a process has the potential to evolve into a financial crisis, and if so, how high the risk would be.

The study has been divided into two main parts except for the introduction and conclusion. The first part consists of the theoretical framework of credit expansions, credit guarantee programs as countercyclical financial measures and risks arising. The second main chapter is devoted to econometric analysis and findings. 


\section{Theoretical Background}

2008-2009 global financial crisis renewed interest in the causes and consequences of excessive credit expansion in the economy. Minsky (1977) and Kindleberger (2000) have put forward over-optimism as a significant factor for credit expansion. Kindleberger (2000) also mentions "herding behavior" by banks, mainly agency problems that lead to the implementation of lending policies by some banks that may be affected by others. Gorton \& Ordonez (2014) informs that credit booms typically precede a financial crisis and credit growth is the best indicator of the likelihood of a financial crisis. Gourinches (2001) states that the greater the credit growth, the higher the probability of a crisis. Dell Aricca \& Marquez (2006) emphasize that banks have lowered their lending standards during periods of rapid credit growth, which in turn worsened the credit portfolio and the banking system became vulnerable to financial pressure as downside risks to the economy arise. Jorda, Schullick \& Taylor (2011), Davis, Mack, Phoa \& Vandenabeele (2016) suggest that excessive credit expansion is the best indicator of the financial crisis and that this relationship is strengthened when it is combined with the increasing current account deficit. In a similar study; Schularick \& Taylor (2012) have argued that successive economic instability is caused by a bad credit expansion period. They argue that the main reason for this is probably the result of the financial system's operational management and its regulatory failures. Levine (2005) states that credit can rapidly grow mainly in financial deepening, in normal upswings and excessive cyclical fluctuations. Elekdag \& Wu (2013), show that balance sheets of banks and companies deteriorate during an excessive credit expansion, overheating in the economy takes place together with large capital flows, the current account deficit increases, asset price shows an upward trend, and domestic demand is strong.

\section{Determination of Excessive Credit Expansion}

The determination of credit expansion is usually done statistically or with econometric models. In the statistical method Mendoza \& Terrones $(2008,2012)$, Gouriches (2001), Barajas, Dell'Ariccia \& Levchenko (2007), Tornell \& Westermanm (2002), IMF(2011); Dell'Ariccia et al., (2016), Arena et al., (2015) compare country's Credit to GDP ratio or real credit to per capita ratio by using the positive deviations from the trend when deviations pass a certain threshold. In these studies, there are differences in credit variables and threshold selection in determining excessive credit expansion.

Apart from statistical methods, in some studies, econometric methods are used to determine the long-term equilibrium level of credit or credit growth as a function of 
economic fundamentals in all selected countries. Then the periods of excessive credit expansion for all selected countries as points above the long-run equilibrium levels are determined (Boissay, Collard \& Smets, 2006; Cottarelli, Dell'Ariccia, \& Vladkova-Hollar, 2005; Égert, Backé \& Zumer, 2007; Kiss, Nagy \& Vonnák, 2006; Hansen \& Sulla, 2013).

\section{What is Systemic Risk?}

IMF, FSB, and BIS (2009) define systemic risk in their work for the G20 as " risk of disruption to financial services that is caused by an impairment of all or parts of the financial system and has the potential to have serious negative consequences for the real economy." BIS (2010: 2) informs that financial services include credit intermediation, risk management and payment services. It also states that the lack of a clear definition of systemic risk is due to time, economy, special circumstances, as well as lack of knowledge about the behavior of the financial system, its interaction with the economy and its sensitivity to policy interventions. Tunay (2014) states that systemic risk in banking reflects the interaction between the negative performance of institutions in general terms.

\section{The Definition of Procyclicality}

Crediting is one of the main factors which supports the procyclical behavior of banks. While the economy starts to grow, and interest rates go down, the investment projects begin to become feasible for banks. Consequently, credit stock in the banking sector starts to increase.

Procyclicality generally refers to mechanisms of a mutually reinforcing mechanism. It strengthens the dynamics in business fluctuations (BIS, 2008). This positive feedback mechanism is destructive and more visible, especially at times when the economy or financial system is under stress. In such a period, financial institutions incur losses, their capital bases deteriorate, and borrowing terms worsen in the market. They are forced to cut credits and sell assets in their portfolio, which in turn weakens the economy. As a result, reducing the financial strength of the financial institutions increases their default or bankruptcy risks.

\section{Procyclicality and the Bank Balance Sheets}


It would also be useful to consider the effect of the procyclicality on bank balance sheets. In a financial system, assets are constantly marked-to-market, which means that changes in prices are immediately reflected in the balance sheets.Net value of all the financial intermediaries in the financial system are effected continuously. Especially the equity capital of banks is vulnerable to changes when the balance sheets are highly leveraged. The financial intermediaries actively adjust their balance. In other words, during periods of economic growth, the use of leverage is increased, and during periods of contraction, it is reduced. "Leverage is in fact, procyclical which can be seen as a consequence of the active management of balance sheets by financial intermediaries who respond to changes in prices and measured risk" (Adrian \& Shin,2010).

\section{Countercyclical Financial Regulations}

The global financial crisis has led to the focus on procyclicality within the macroprudential framework. Finance, and especially the nature of banking activities, inherently increase the impact of business cycles and are procyclical.

The macroprudential framework is concerned with systemic risks both in the time dimension (procyclicality) and in cross-cutting dimensions (concentration and interdependence). During periods of growth, credit expansion improves ahead of economic growth. In periods of economic recession, the creditworthiness of the borrowers - as a result of reduced corporate profits- will decline, household income and wealth will go down. Worsening collateral values, increasing risk perception and tightening lending standards will make lending more difficult. It leads to worsening economic expectations. There are two main objectives of countercyclical financial regulations: to increase the flexibility of the financial system in the event of a possible downturn in the future, to lean against the wind in the cycle, to prevent excessive credit expansion and to prevent the accumulation of imbalances in an upswing (Haocong, 2011). After the 2008 financial crisis, public credit guarantee programs have been used as a countercyclical financial tool.

\section{Public Guarantee Programs}

It is known that the first public guarantee program was founded in Holland in 1915, but most government-run guarantee programs were established in the 1990s 2000s (Pombo \& Herrero, 2003). Public guarantee programs first began to be used in the 1950s, and they were used in 70 different countries in various forms until the early 
2000s. Governments often used these programs for companies which had not been not adequately credited by private-sector financial intermediaries, for small and medium-sized firms, newly established companies and for innovative firms that developed new products. Lately, public guarantee programs gained more importance for both developed and developing countries and were widely used. After the financial crisis of 2008-2009, Public Guarantee Programs in Canada, Chile, Finland, Germany, and South Korea were started to be used widely in response to the decrease in loans of private banks. Many countries rapidly strengthened their guarantee programs with the total amount of funds available, the number of companies eligible for funding, the percentage of a loan guaranteed and/or size of the guaranteed loans. During the financial crisis, countercyclical use of credit guarantee programs has led to the expansion of both the scale and scope of the programs (Gozzi \& Schmukler 2016). The European Commission, for example, has made decisions to facilitate the financial access of companies operating in the European Union countries through publicly funded guarantees and credit support. As a general method; the maximum credit guarantee amount has been increased. In 2008, the guarantee given by the public in France was 50-60\%. This rate was later raised to 90\% in France, and 75\% in the UK.

Public guarantee schemes vary significantly in terms of the guaranteed loan amount. For example, some of the largest are located in Asia. In 2013 the guarantee system in Japan, with a total of 3.1 million guarantees, about 305 billion US dollars and a guaranteed new loan of about 713,000, was the largest of the programs. The secondlargest program was conducted in South Korea. The 2013 stock guarantee amounted to 400,000 , and the total size reached 40 billion USD, in other words, about $4 \%$ of South Korea's GNP. When other guarantee programs are looked into, it is generally seen that the size is less than 100,000, and two-thirds of them guarantee a credit below 1,000 per annum. (Beck, Klapper \& Mendoza, 2010).

In terms of both economic theory and empirical findings, the effects of these programs on the volume of economic activity due to the financing of firms are not very clear (Gozzi \&Schmukler, 2016; D'Ignazio \& Menon, 2013). In developed countries, it is seen that if the credit guarantee programs are designed and managed correctly, public resources will not be wasted, productivity, innovation, growth, employment, and exports will increase. Sweden is a good example of such programs (Cowling, 2017).

Chatzouz et al. (2017), in the aftermath of the Global Crisis, stated that credit guarantee programs in Western Europe made significant contributions to increase the volume of economic activity by extending their activities. However, despite this response to the crisis, it was determined that the credit demands of the small and 
medium-sized enterprises (SMEs) were insufficient, and this limited the use of credit guarantees. It shows that credit guarantee programs have positive real economic impacts that depend on the credit demands of firms.

The effects of credit guarantee programs are also under discussion in emerging economies. Zhang \& Ye (2010), for example, examined the results obtained after running a credit guarantee program for ten years in small and medium enterprises in China. They have determined that the effectiveness of the guarantee program has decreased for many reasons, such as risk-sharing and increased collateral. Zhang and Ye (2010) point out that to increase the efficiency of the program, both the development of a fund-raising mechanism and indemnity mechanism should be improved, and appropriate conditions should be established for the companies to develop new products and services.

The results of Liang et al. (2017) research on the effectiveness of the credit guarantee program implemented in South Korea are also stimulating in this regard. Their findings show that banks' cost-effectiveness decreased when loans extended to small and medium-sized firms.

This decline is caused by information asymmetry. However, they stated that the credit guarantee programs could increase the cost-effectiveness of banks and that the guarantee system should share the risk of banks reasonably. In other words, when the state and banks reasonably share the risk, the system becomes effective, and the efficiency decreases significantly when the share is against the banks.

Researchers like Cowling (2017), Gozzi \& Schmukler (2016) state that the success and financial sustainability of the guarantee programs depend on an accurate design. Cowling (2017) argues that the use of guarantee programs as a policy tool should determine whether the main objective is economic, socioeconomic or regional development. It stresses the importance of considering the possible effects of different parameters in the design of credit guarantee programs and the determination of their possible limits for the program to operate smoothly. Chatzouz et al., (2017), researchers such as Gozzi and Schmukler (2016) found that the limitations of the programs as well as the design mistakes, the slow processing of the bureaucracy, and the guarantees required are the crucial factors that reduce the success of the credit guarantee programs. In a study carried out by the Asian Development Bank (2016), the importance of sectoral targeting was emphasized, and it was stated that studies should be carried out on the collateral plans, monitoring and cancellation processes to be applied in case of default for the supported companies.

On the other hand, such programs have some handicaps for banks. While playing a role as a capital increase for banks, difficulties in practice due to the complexity of 
the regulations, the lack of transparency, etc. have reduced the level of success (Chatzouz et al., 2017). It has been determined that credit guarantee programs change the risk allocation, but do not eliminate the default risk, and if the correct pricing is not performed, the price will reflect both the probability of default risk and the risk will be transferred to the debtor (Asian Development Bank, 2016).

\section{Econometric Analysis}

\section{Analysis Method and Structure of the Models}

Cross-section dimensions of many panel data sets may be bigger compared to their time dimensions. In this case, the generalized least squares estimator can produce effective results. In this context, linear panel data models (such as fixed or randomeffects models) or generalized linear models which estimate the mean of the population (panel logit, probit, etc.) may be used. However; feasible generalized least squares (FGLS) estimator is a more effective method of estimation in the case that there is a cross-sectional correlation, first degree autoregressive (AR(1)) correlation coefficient within the cross-sections or in that heteroskedasticity exists in the sample in which cross-sectional correlation may not present. (Sanchez, 2012; Wooldridge, 2010: 298-299). As will be explained in the next sub-section, the method in question was preferred as an analysis tool since the number of crosssections of the data set to be used in our study exceeds the number of observations per cross-section.

The general structure of a linear panel data model can be shown as follows:

$$
y_{i t}=X_{i t} \beta+\varepsilon_{i t}
$$

In the equation numbered $(1) \mathrm{i}=1, \ldots, \mathrm{m}$ indicates the number of units or crosssections (panel), $\mathrm{t}=1, \ldots, \mathrm{T}_{\mathrm{i}}$ indicates the number of observations in cross-section $\mathrm{i}$. $\mathrm{y}_{\mathrm{it}}$ symbolizes the dependent variable and $\mathrm{X}_{\mathrm{it}}$ symbolizes the independent variables vector. $\varepsilon_{i t}$ are the error terms assumed to be normally distributed with zero mean and $\sigma^{2}$ variances. The general structure of the variance matrix of error terms is as follows (StataCorp, 2013: 159):

$$
\Omega=\left[\begin{array}{cccc}
\sigma^{2} I & 0 & \cdots & 0 \\
0 & \sigma^{2} I & \cdots & 0 \\
\vdots & \vdots & \ddots & \vdots \\
0 & 0 & \cdots & \sigma^{2} I
\end{array}\right]
$$


Variances of cross-sections (panels) in many panel data sets are different from one another. For example, this situation shall be observed when the branches or representative offices of a big company spread in a broad geographical area covering several countries, several provinces within a country in different settlement places. In this case, the diagonal of the matrix numbered (2) shall be defined with variances special to the cross-section (StataCorp, 2013,p.159; Sanchez, 2012, p. 42):

$$
\Omega=\left[\begin{array}{cccc}
\sigma_{1}^{2} I & 0 & \cdots & 0 \\
0 & \sigma_{2}^{2} I & \cdots & 0 \\
\vdots & \vdots & \ddots & \vdots \\
0 & 0 & \cdots & \sigma_{m}^{2} I
\end{array}\right]
$$

Error terms may be correlated in certain samplings. Furthermore, they may have variances with different scales as well. In this case, the structure of the variance matrix shall become more complex (StataCorp, 2013, p. 160):

$$
\Omega=\left[\begin{array}{cccc}
\sigma_{1}^{2} I & \sigma_{1,2} I & \cdots & \sigma_{1, m} I \\
\sigma_{2,1} I & \sigma_{2}^{2} I & \cdots & \sigma_{2, m} I \\
\vdots & \vdots & \ddots & \vdots \\
\sigma_{m, 1} I & \sigma_{m, 2} I & \cdots & \sigma_{m}^{2} I
\end{array}\right]
$$

If the model is to be estimated considering the cross-sectional correlation, the crosssections to be analyzed should have a balanced structure. The structure of the variance matrix is defined more generally in the models with auto-regression, and its diagonal is composed of unit matrices. Since the cross-section correlations in data sets with a short time dimension are almost equal, the use of a general autoregression parameter in limitation of the model shall be the most accurate selection.

The feasible generalized least squares estimator can be defined as follows (Cameron \& Miller, 2015, StataCorp, 2013, p. 163):

$$
\begin{gathered}
\hat{\beta}_{G E K}=\left(X^{\prime} \hat{\Omega}^{-1} X\right)^{-1} X^{\prime} \hat{\Omega}^{-1} y \\
\operatorname{Var}\left(\hat{\beta}_{G E K}\right)=\left(X^{\prime} \hat{\Omega}^{-1} X\right)^{-1}
\end{gathered}
$$


Variance matrix $(\Omega)$ is the Kronecker product of the unit matrix where covariance matrices of residuals $\left(\Sigma_{\mathrm{i}, \mathrm{j}}\right)$ and dimensions are equal to the number of observations per cross-section (StataCorp, 2013, p. 163):

$$
\Omega=\Sigma_{m \times m} \otimes I_{T_{i} \times T_{i}}
$$

The covariance matrix of the residuals in the equation numbered (5) is calculated as follows, and it is used in the calculation of standard errors of coefficient estimations and $\mathrm{t}$ and/or $\mathrm{z}$ tests as well (taking the reciprocal) (Wooldridge, 2010: 298; StataCorp, 2013, p. 164):

$$
\hat{\Sigma}_{i, j}=\frac{\hat{\varepsilon}_{i}^{\prime} \hat{\varepsilon}_{j}}{T}
$$

Maximum likelihood (ML) estimations of the models can be made as well based on the feasible generalized least squares estimator. For this purpose, FGLS estimation is repeated by being updated in each step until autoregression of the residuals does not remain.

In this study, the channels through which bank credits (Crd) opened for the private sector and non-performing loans ( $\left.\mathrm{Crd}^{\text {nonperf. }}\right)$ are affected by systemic risk, and by the public guarantees given to the bank credits shall be researched. BIS recommended the credit-to-GDP gap ratio as systemic risk criterion in the recent period for the banking authorities of the countries included in Basel Consensus. Within this framework, the credit-to-GDP gap and public guaranteed bank credits have been included in the model as the primary explanatory variables.

Golemi (2015), Antunes et al. (2018), Alessi \& Detken (2018) emphasize the importance of the credit gap as a leading indicator reflecting bank crises in recent experimental studies. Golemi (2015), Alessi and Detken (2018) stated that unsustainable credit developments lead to the accumulation of systemic risks in terms of financial stability. In this regard, Antunes et al. (2018), Alessi \& Detken (2018) have developed alternative early warning models. In addition to some other variables, the credit gap was included in both models.

Credit-to-GDP gap ( $\left.\mathrm{Crd}^{\mathrm{Gap}}\right)$ is calculated as the deviation of the proportion of the bank credits opened for the private sector to GDP from its own long term equilibrium values. And the credit guarantees $\left(\mathrm{Crd}^{\mathrm{Guar}}\right)$ have been calculated considering the public guarantees given to the bank credits opened for small and medium-sized enterprises for the countries in the sample. The details of the calculation are explained in the next sub-section. 
Credits and the credit risk they are exposed to are strongly affected by the fluctuations in the economic activity volume. Many empirical studies suggesting the accuracy of this judgment are available in the relevant literature. In this respect, economic growth has been included in the model as a control variable in addition to the aforementioned variables. In this manner, it shall be possible to observe in the sample examined how the bank credits opened for the private sector, and nonperforming bank credits have been affected by economic growth. The model which makes up the basis for the analyses has been presented as follows:

$$
\begin{gathered}
y_{i t}=\beta_{0}+\beta_{1} \operatorname{Crd}_{i t}^{\text {Gap }}+\beta_{2} \operatorname{Crd}_{i t}^{\text {Guar }}+\beta_{3} \operatorname{Grw}_{i t}+\varepsilon_{i t} \\
y_{i t}=f\left\{\operatorname{Crd}, \operatorname{Crd}^{\text {nonper }}\right\}
\end{gathered}
$$

In equation (6); $y_{i t}$ is the dependent variable and symbolizes the credits in the first model analyzed and non-performing credits in the second one. $\beta_{i}(i=0, \ldots, 3)$ symbolizes the estimated parameters vector and $\varepsilon_{i t}$ symbolizes the error terms the features of which are defined previously.

\section{Data Set}

A data set covering 26 developed countries and significant emerging economies has been used in the study. The countries in the sample have been presented in Appendix Table 1. The panel data set prepared contains the annual date of the period of 20072014 and has a balanced panel structure. The total number of observations is 832 . The definitions of the variables in the model numbered (6), which make up the basis for estimations and data sources have been given in Table 1, and definitive statistics have been given in Table 2 .

\section{Table 1}

Variable Definitions and Data Sources

\begin{tabular}{lll}
\hline Variable & Definition & Source of Data \\
\hline Crd & Credits: & $\begin{array}{l}\text { World Bank Global } \\
\text { Financial Development } \\
\end{array}$ \\
& $\begin{array}{l}\text { The Ratio of Bank credits granted for Private Sector } \\
\text { to GDP }\end{array}$ & Database, 2017
\end{tabular}


Krd ${ }^{\text {Nonperf. }} \quad$ Non-performing Credits:

The ratio of non-performing bank credits to total credits

Grwth Growth:

Growth rate calculated from GDP series measured by constant prices.

Crd ${ }^{\text {Gap }} \quad$ Credit-to-GDP gap:

The ratio of bank credits granted to the private sector to GDP and deviation from its long-term trend ${ }^{1}$

$\mathrm{Crd}^{\text {Guar }}$ Credit guarantees:

Public guarantees were given to bank credits of small and medium-sized enterprises ${ }^{2}$
World Bank Global

Financial Development

Database, 2017

IMF, World Economic Outlook Database, October 2017.

Bank for International Settlements / BIS

August 2017 period statistics.

OECD Scoreboard:

Financing SMEs and Entrepreneurs 2016, s. 72.

(1) This variable is measured by its deviation from the Hodrick-Prescott trend. It has been calculated by BIS.

(2) Natural logarithms of the data compiled in the national currency of the relevant country have been taken.

\section{Table 2}

Descriptive Statistics

\begin{tabular}{llllll} 
& Observation & Average & Std.Deviation & Min. & Max. \\
\hline Crd & 208 & 90.870 & 53.214 & 16.560 & 272.600 \\
Crd $^{\text {Nonperf. }}$ & 208 & 4.387 & 4.636 & 0.200 & 33.780 \\
Crd $^{\text {Gap }}$ & 208 & 0.00000192 & 5.501 & -25.166 & 20.188 \\
Crd $^{\text {Guar }}$ & 208 & 2.522 & 1.518 & -0.00437 & 5.574 \\
Grwth. $^{2}$ & 208 & 1.433 & 3.606 & -14.724 & 11.113 \\
\hline
\end{tabular}

Correlations of the variables with one another have been presented in Table 4. Examining the correlation coefficients, it is observed that credits and non-performing 
credits have strong interactions with the credit-to-GDP gap, credit guarantees, and growth.

\section{Table 3}

\section{Correlation Coefficient Matrix}

\begin{tabular}{lrrrrr}
\hline & Crd. & Crd.Nonperf. & CrdGap & CrdGuar & Growth \\
\cline { 2 - 6 } Crd & 1.0000 & & & & \\
Crd $^{\text {Nonperf. }}$ & -0.0766 & 1.0000 & & & \\
Crd $^{\text {Gap }}$ & 0.1090 & 0.0739 & 1.0000 & & \\
Crd $^{\text {Guar }}$ & -0.1979 & 0.1121 & 0.0414 & 1.0000 & \\
Grwth. & -0.2163 & -0.3079 & -0.4218 & -0.0709 & 1.0000 \\
\hline
\end{tabular}

\section{Findings}

Since the panel data set we used consisted of developed and emerging economies and each had different structural features, it has been assumed that cross-sections exhibited heteroscedasticity and error terms had autocorrelation peculiar to the crosssection.

In order autocorrelation of error terms to be eliminated and to make the estimation more effectively, the maximum likelihood (ML) method has been used. The results of estimation have been presented in Table 4.

Examining the results, it is observed that the coefficient significance of both models was extremely high, and the model passed the Wald test indicating general significance. In the estimation results of the first model, it is observed that the proportion of bank credits opened for the private sector to GDP was affected positively by all variables in the model. Because of the strong relationship between economic growth and bank loans, it is natural that there is a strong relationship between the credit gap used as a systemic risk criterion and the fluctuations in the volume of economic activity.

The banks make more credits available in expansion periods of the economy and credits increase above their long term equilibrium values. On the other hand, total credit volume shall narrow in an economic slowdown since the banks behave involuntarily in opening new credits and this time credits will decrease below their long term trend. Undoubtedly, the provision of a guarantee by the state for the credits 
opened by the banks for small and medium-sized enterprises shall incite SME credits of banks and lead to an increase in total credits. Consequently, it is a natural result that credit guarantee programs positively affect the bank credits opened for the private sector.

However, this positive effect cannot always be achieved. Regardless of the level of development of the country in which the program is implemented, the expected results may not be obtained due to a lack of sufficient demand for credit guarantees, incorrect design of the program or incorrect selection period. For example, the study of D'Ignazio \& Menon (2013) on Italy showed that the credit guarantee program applied did not have an impact on total credit volume, although it led to an increase in long-term loans and a decrease in loan rates. More importantly, there was no significant increase in the volume of real economic activity as a result of this program.

\section{Table 4}

UGEK-Maximum Likelihood Estimation Results of the Model Numbered (6)

\begin{tabular}{|c|c|c|c|c|c|c|}
\hline \multirow{2}{*}{$\begin{array}{l}\text { Independent } \\
\text { Variable }\end{array}$} & \multicolumn{6}{|c|}{ Dependent Variables } \\
\hline & \multicolumn{3}{|c|}{ Crd } & \multicolumn{3}{|c|}{$\mathrm{Crd}^{\text {Nonperf. }}$} \\
\hline Crd & Coefficient & z Test & $\begin{array}{c}\mathrm{p} \\
\text { Value }\end{array}$ & Coefficient & z Test & $\begin{array}{l}\mathrm{p} \\
\text { Value }\end{array}$ \\
\hline $\mathrm{Crd}^{\text {Nonperf }}$ & 1.07216 & 184.680 & 0.000 & 0.02355 & 2.560 & 0.011 \\
\hline $\mathrm{Crd}^{\mathrm{Gap}}$ & 0.22640 & 3.140 & 0.002 & 0.20246 & 2.840 & 0.005 \\
\hline $\mathrm{Crd}^{\text {Guar }}$ & 0.02091 & 3.040 & 0.002 & -0.04911 & -3.370 & 0.001 \\
\hline Grwth & 74.79837 & 287.190 & 0.000 & 2.56576 & 11.530 & 0.000 \\
\hline \multicolumn{7}{|l|}{ Wald Tests: } \\
\hline Ki Square: & 60960.86 & & & 39.710 & & \\
\hline p -Value: & 0.0000 & & & 0.000 & & \\
\hline
\end{tabular}

The estimation results of the second model indicate that the proportion of nonperforming bank credits to GDP, the dependent variable was positively affected by the variables except for growth. It is reasonable to expect to have significant defaults in credit repayments in shrinkage periods of economies. The companies the sales volumes of which decrease, and which have difficulty in collection of their receivables may delay payments of their credit obligations or may even completely become insolvent. The severity of such developments depends on the duration as 
well as penetration of recession. On the other hand, defaults in credits may be observed more in the credits of companies operating in specific sectors since certain sectors, including tourism, construction, and so on, tend to be affected more negatively by recession periods than other sectors together with food and transportation.

Non-performing bank credits are a significant indicator of credit risk. In this respect, the fact that this has a positive relationship with the credit gap should be taken normally. The more credit-to-GDP gap increases, the more systemic risk shall rise, and default risk for the credits shall increase in direct proportion accordingly. However, the relation of credit guarantees with non-performing credits should be assessed more carefully. Credit guarantees are a measure sought by the state to subsidize certain sectors in regular periods and to invigorate the economy in periods of recession.

Since credit repayments are not much interrupted when the economy grows or continues, generally, credit risk shall naturally be low. However, in periods of recession, particularly if the economy is in a deep and comprehensive stopover period; credit guarantees have the potential of increasing the risk for bank credits. According to the estimation results, credit guarantees having a positive effect on nonperforming credits indicate the significance of this potential.

These findings indicate that the credits increase in the case the state gives a guarantee for bank credits in addition to economic expansion periods. Consequently, following policies as credit guarantees in shrinkage periods may expand total credit volume and play a role in the shortening of the period of recession. Additionally, the existence of a serious systemic risk element should be taken into consideration since the credits exhibit a strong procyclicality. The structures and features of the sectors for which credits shall be allocated by the banks should be taken into consideration in determining the applicable guarantees. The credits opened for the companies operating in certain sensitive sectors may have serious default risk. For this reason, credit riskiness of the banks may increase, and significant systemic fragilities may arise.

\section{Result}

A sample covering 26 developed countries and significant emerging economies has been analyzed in the study, and the effects of the credit-to-GDP gap, credit guarantees and economic growth on credits and credit risk have been researched. Since the number of cross-sections of the sample analyzed is quite higher than the 
number of observations per cross-section, the feasible generalized least squares estimator rather than linear panel data techniques, including fixed and random effects, was preferred. This estimator gives more successful results in samples with a low number of observations per cross-section. Furthermore, factors including heteroskedasticity and autocorrelation on the cross-section basis were taken into account considering the different structural features of the countries included in the analysis.

The findings obtained indicate that non-performing credits, significant criteria of both credits and credit risk, are strongly affected by credit gap, credit guarantees, and growth. Credits are affected by all those variables positively. It was observed that banks expand credit supply in growth periods, and the proportion of credits to GDP rise over its own long- term equilibrium values. It is an expected result because it is known from the findings of international empirical studies that credits are a variable strongly influenced by the changes in economic activity. Estimation results have indicated that the effect of economic growth on non-performing credits was negative. This result supports the procyclicality of the credits. Credit volume increases, and default proportions decrease in periods of expansion of economies. On the other hand, in an economic downturn, both credits shrink, and non-performing credits increase. Despite this, the credit gap affects non-performing credits positively. Rises in credit gap generally stem from excessive credit increase and may be effective in the increase of non-performing credits.

Estimation results also indicate that the public credit guarantees increase total credit volume as well. One may say that this effect is independent of the general course of the economy. Namely, credit guarantees may be used as a means of expansive policy in periods of a slowdown in the economy. However, it has also been observed that non-performing credits namely risks of credits of banks were affected by this variable positively. Public guarantees may lead banks to act less selectively while granting credits and cause an increase in their riskiness. On the other hand, the desire to increase credits through this channel in economic recession periods shall lead to a similar effect as well. In this context, crediting the sectors more vulnerable to the effects of recessions has a high- risk potential although the financial structure of companies credited may be reasonably solid. The decrease in the turnovers of such companies and/or their failure to collect their receivables may cause them to become quickly insolvent. The findings suggest that policies for expanding credit stock may have positive effects as well as adverse effects. For this reason, potential results of practices, including credit guarantees, should be analyzed well by decision-makers.

While concluding, it should be noted that the main contribution of the study is to investigate the effectiveness of credit guarantee programs and the risks that may be 
caused by a comprehensive sample of developed and developing countries. However, due to the difficulties encountered in obtaining the data, the options for the methods to be used in the analysis are limited. In the compiled data set, the fact that the number of cross-sections exceeds the number of observations per crosssection constitutes the most important handicap of the study because it has prevented a more detailed econometric analysis.

\section{Acknowledgment}

We would like to thank the reviewers for their invaluable contributions to the development of the work with their opinions and suggestions.

\section{Appendix}

\section{Table 1}

Countries in Analysis.

\begin{tabular}{cc}
\hline Austria & Hungary \\
Belgium & Israel \\
Canada & Italy \\
Chile & Japan \\
Colombia & Mexico \\
Czech Republic & Republic of \\
& Slovakia \\
Denmark & Russia \\
England & Slovenia \\
Estonia & South Korea \\
Finland & Spain \\
France & Thailand \\
Greece & The USA \\
\hline
\end{tabular}


Holland Turkey

\section{References}

Adrian, T. \& Shin, H.S. (2010) The Changing Nature of Financial Intermediation and the Financial Crisis of 2007-09. Federal Reserve Bank of New York Staff Reports.

Arena, M., Bouza, S., Dabla-Norris, E., Gerling, K. \& Njie,L (2015) Credit Booms and Macro Economic Dynamics: Stylized Facts and Lessons for Low-income Countries. International Monetary Fund, WP 15/11.

Asian Development Bank. (2016). Credit Guarantees - Challenging Their Role in Improving Access to Finance in the Pacific Region, ABD, Manila, Philippines.

Barajas, A., Dell'Ariccia, G.\& Levchenko, A. (2007) Credit booms: the Good, the Bad, and the Ugly. Unpublished: International Monetary Fund.

Beck, T., Klapper, L. F. \& Mendoza, J.C. (2010) The Typology of Partial Credit Guarantee Funds around the World. Journal of Financial Stability vol.6, p.p. 10-25.

BIS, (2010) Macroprudential instruments and frameworks: a stocktaking of issues and experiences", CGFS Papers, No.38 Available from: http://www.bis.org/publ/cgfs38.pdf./ [Accessed 19th June 2019].

BIS. (2008) Addressing financial system procyclicality: a possible framework. Note for FSF Working Group on Market and Institutional Resilience. Available from: http://www.financialstabilityboard.org/publications/r_0904e.pdf.:1./ [Accessed 25th May 2019].

Boissay, F., Collard, F. \& Smets, F. (2016) Booms and banking crises. Journal of Political Economy. 124(2), pp. 489-538.

Borio, C. \& Lowe, P. (2002) Asset Prices, Financial and Monetary Stability: Exploring the Nexus. BIS Working Papers, No.114.

Cameron, C. A. \& Miller, D.L. (2015) A Practitioner's Guide to Cluster-Robust Inference. Journal of Human Resources, vol.50, pp.317-372.

Chatzouz, M., Gereben, Á., Lang, F.\& Torfs, W. (2017) Credit Guarantee Schemes for SME lending in Western Europe. European Investment Fund Research \& Market Analysis Working Paper No. 2017-41, June.

Cottarelli,C., Dell'Ariccia,G.\& Vladkova-Hollar, I. (2005) Early birds, late risers, and sleeping beauties: bank credit growth to the private sector in central and eastern Europe and in the Balkans. Journal of Banking \& Finance vol.29 (1), pp.83-104.

Cowling, M. (2017) Loan Guarantee Schemes as a Policy Instrument for Financing Entrepreneurial Businesses. Swedish Agency for Growth Policy Analysis Paper, No. 2016/084, January.

Davis, E. P. \& Dilruba, K. (2008) Comparing Early Warning Systems for Banking Crises. Journal of Financial Stability, vol.4, no.2, pp. 89-120.

Davis, J. S., Macka, A., Phoab, W.\& Vandenabeele, A. (2016) A Credit booms, banking crises, and the current account. Journal of International Money and Finance, vol.60, pp.360-377.

Dell'Ariccia, G., Igan, D., Laeven, L.\& Tong, H. (2016) Credit booms and macro financial stability. Economic Policy, vol. 31(86), p.p.299-355. 
D'Ignazio, A. \& Menon, C. (2013) Evaluating Credit Guarantees for SMEs: Evidence from Italy. Annual DNB Research conference: The Impact of Credit on the Dynamics of SMEs.

Égert, B., Backé, P. \& Zumer, T. (2007) Private-sector Credit in Central and Eastern Europe: New (Over) Shooting Stars? Comparative Economic Studies vol. 49(2). pp.201-231.

Elekdag, S. \& Wu, Y. (2013) Rapid Credit Growth in Emerging Markets: Boon or Boombust? Emerging Market Finance and Trade, vol.49(5), pp.45-62.

Frömmel, M. \& Tosten, S. (2006) Bank Lending and Asset Prices in the Euro Area. RWI Discussion Papers, No.42.

Gerdesmeier, D., \& Roffia, B. \& Reimers, H.E. (2009) Asset price Misalignment and the Role of Money and Credit. European Central Bank, Working Paper Series, No.1068.

Gorton, G. \& Ordoñez, G. (2014) Collateral Crises American Economic Review, 104(2): 343 378 http://dx.doi.org/10.1257/

Gourinchas, P-O., \& Valdes, R.\& Landerretche, O. (2001) Lending booms: Latin America and the world. Economia, Journal of Latin American and Caribbean Economic Association, Vol.1, No.2, pp.47-99.

Gozzi, J.C. \& Schmukler, S. (2016) Public Credit Guarantees and Access to Finance. Warwick Economics Research Paper. Sn.1122.

Gruss, B. \& Sgherri, S. (2009) The Volatility Costs of Procyclical Lending Standards: An Assessment Using a DSGE Model.IMF Working Paper, No. WP/09/35.

Hansen, N-J.H. \& Sulla, O. (2013) Credit Growth in Latin America: financial development or credit boom? IMF Working Paper, No.13/106.

Haocong, R. (2011) Countercyclical Financial Regulation. World Bank Policy Research Working Paper, No.5823, p.4. Available from: https://openknowledge.worldbank.org/bitstream/handle/10986/3587/WPS5823.pdf?s equence $=1 /$ [Accessed 20th April 2019].

IMF World Economic Outlook. (2004) Are Credit Booms in Emerging Markets a Concern? Chapter IV pp. 152-153.

IMF, FSB \& BIS. (2009) Guidance to Assess the Systemic Importance of Financial Institutions, Markets and Instruments: Initial Considerations" Report to the G-20 Finance Ministers and Central BankGovernors. Available from: https://www.imf.org/external/np/g20/pdf/100109.pdf./ [Accessed 20th April 2019].

Jokivuolle, E., Kiema, I. \& Vesala, T. (2009) Credit Allocation, Capital Requirements and Procyclicality. Bank of Finland Research Discussion Papers, No. 23.

Jordà, Ò., Schularick, M.\& Taylor, A. M. (2011) Financial crises, credit booms, and external imbalances: 140 years of lessons. IMF Economic Review, Vol.59, No.2, pp.340-378.

Kindleberger, C. (2000) Manias, Panics, and Crashes: A History of Financial Crises New York. John Wiley and Sons.

Kiss, G., Marton, N. \& Vonnák, B. (2006) Credit growth in central and Eastern Europe: convergence or boom? MNB Working Papers, No.2006/10

Levine, R. (2005) Finance and growth: theory and evidence, Handbook of Economic Growth, pp. 865-934.

Liang, L-W., Huang B-Y., Liao, C-F. \& Gao, Y-T. (2017) The Impact of SMEs' Lending and Credit Guarantee on Bank Efficiency in South Korea. Review of Development Finance, 7(2), 134-141.

Llaudes, R., Salman, F. \& Chivakul, M. (2010) The Impact of the Great Recession on Emerging Markets. IMF Working Papers, No. WP/10/237. 
Mendoza, E. G. \& Terrones, M. E. (2012) An anatomy of credits booms and their demise. NBER Working Paper Series, No.18379.

Mendoza, E. G. \& Terrones, M. E. (2008). An Anatomy of Credit Booms: Evidence from Macro Aggregates and Microdata, National Bureau of Economic Research, No. w14049.

Minsky, H. (1977) The Financial Instability Hypothesis: An Interpretation of Keynes and an Alternative to 'Standard' Theory, Nebraska Journal of Economics and Business, $165-$ 16.

Misina, M. \& Tkacz, G. (2009) Credit, Asset Prices, and Financial Stress. International Journal of Central Banking, Vol.5, No.4(4), pp. 95-112.

OECD. (2013) SME and Entrepreneurship Financing: The Role of Credit Guarantee Schemes and Mutual Guarantee Societies in Supporting Finance for Small and Medium-sized Enterprises.

OECD. (2012) Financing SMEs and Entrepreneurs. An OECD Scoreboard 2012. OECD Publishing, Paris.

OECD. (2010) Assessment of Government Support Programs for SME's and Entrepreneurs' Access to Finance during the Crisis."

Pombo, P. \& Herrero, A. (2003) Los Sistemas de Garantías para la Micro y la Pyme en una Economía Globalizada. DP Editorial.

Repullo, R., Saurina, J.\& Trucharte, C. (2009) Mitigating the Procyclicality of Basel II, Macroeconomic Stability and Financial Regulation: Key Issues for the G20 (Eds.) M.Dewatripont, X. Freixas ve R. Portes, London: Centre for Economic Policy Research (CEPR), pp. 105-112.

Rheinberger, K. \& Summer, M. (2008) Credit Portfolio Risk and Asset Price Cycles. Computational Management Science, 5(4), pp. 337-354.

Riiser, M. D. (2008) Asset Prices, Investment and Credit -What Do They Tell Us About Financial Vulnerability? Economic Commentary, No.6.

Riiser, M. D. (2005) House Prices, Equity Prices, Investment and Credit - What Do They tell us about Banking Crises? A Historical Analysis Based on Norwegian Data. Norges Bank Economic Bulletin, No:3, 2005, pp.145-154.

Sanchez, G. (2013) Fitting Panel Data Linear Models in Stata, Stata Corp LP. Stata Corp. Stata - Longitudinal-Data / Panel Data Reference Manual, Release 13, College Station, Texas, Stata Press. (2012).

Schularick, M. \& Taylor, A. M. (2012) Credit booms gone bust: monetary policy, leverage cycles, and financial crises, 1870-2008. Am Economic Review, Vol.102, No.2, p.p.1029-1061.

Tornell, A. \& Westermann, F. (2002) Boom-bust cycles in middle-income countries: facts and explanation. IMF Economic Review, Vol. 49(1), pp.111-155.

Tunay, K. B. (2014) Ekonomik Döngüler: Krizler, Durgunluklar ve Türkiye ye Dair Tespitler [Economic Cycles: Crises, Recessions and Findings Regarding Turkey]. Ankara, Nobel Academic Publishing.

Wooldridge, J. M. (2010) Econometric Analysis of Cross Section and Panel Data. 2nd Edition, Cambridge, Massachusetts, The MIT Press.

World Bank. (2013) Rethinking the Role of the State in Finance. Global Financial Development Report, Washington, DC.

Zhang, P. \& Ye, Y. (2010) Study on the Effective Operation Models of Credit Guarantee System for Small and Medium Enterprises in China. International Journal of Business and Management, 5(9), 99-106. 